\section{Lembaran Sejarah}

\title{
A Book Industry in Transition: The Shortage of Books in Indonesia in the Late 1940s and 1950s'
}

\section{ELINE SOPHIE KORTEKAAS}

University of Amsterdam

Email: e.s.kortekaas@uva.nl

\begin{abstract}
This paper examines the book shortage crisis in Indonesia in the late 1940s and 1950s. After the Second World War, several Dutch colonial publishing houses decided to continue their businesses in Indonesia. During the second half of the 1940s there seemed to be an evergrowing demand for books in Indonesia, and by the end of 1949, several Dutch newspapers reported a so-called book crisis. A small booklet entitled De boekennood van modern Indonesië (Book Crisis of Modern Indonesia) (1949) seemed to be the herald of this alarming news. It was written by A.P. van Schieveen, who was a board member of the Vereniging van Indische Boekhandelaren, a society of Dutch book traders which had been established in 1926." In this booklet he emphasizes the importance of reading for Indonesia's development, but also warns the Dutch publishing industry of the fact that the preferred second language seems to have become English. As a solution to support the continuing use of the Dutch language, he urged the Dutch publishing industry to distribute large quantities of Dutch books all over Indonesia. G. Ockeloen, the editor of Madjallah perdagangan buku di Indonesia/Maandblad voor de boekhandel in Indonesië (1949), responded to this matter. According to Ockeloen, Van Schieveen was stating the obvious, and he wrote that there was an even larger crisis going on, which was the shortage of books in Bahasa Indonesia.
\end{abstract}

\section{Abstrak}

Artikel ini mengkaji kelangkaan buku di Indonesia pada akhir dedade 1940an dan selama dekade 1950an. Setelah berakhirnya Perang Dunia II, beberapa penerbit dari masa kolonial Belanda memutuskan untuk tetap beroperasi di Indonesia. Dalam paruh kedua 1940an, terjadi lonjakan kebutuhan akan buku di Indonesia, dan pada akhir tahun 1949 beberapa surat kabar Belanda melaporkan adanya "krisis buku".

\section{Keywords:}

Dutch publishers; Indonesia; Indonesian and Dutch books; PostWorld War Two

\section{Kata Kunci:} buku Indonesia dan Belanda; Indonesia; ...

*) Mededeelingen van de Vereeniging van Indische boekhandelaren, no 1. September 1926, p. 2. The society was established by the Dutch colonial publishing houses G. Kolff \& Co., Vorkink and Visser and in September 1926 the following publishing houses were a member of this society: N.V. G. Kolff \& Co. (Jakarta), Boekhandel Visser \& Co (Jakarta and Bandung), Boekhandel en Drukkerij De Archipel (Bogor), N.V. Mij Vorkink (Bandung), G.C.T. Van Dorp \& Co. (Bandung, Semarang, Surabaya,), Buning (Yogyakarta), Nijland (Surabaya), Varekamp \& Co. (Medan), Boekhandel De Delicourant (Medan), Firma Sluijter (Surabaya, Malang), Boekhandel en drukkerij Celebes (Makassar), Furhi (Surabaya) and Van Ingen (Surabaya). 
Sebuah booklet berjudul "De boekennood van modern Indonesië" (Krisis Buku Indonesia Modern, 1949) menggambarkan darurat-buku saat itu. Booklet tersebut ditulis oleh A.P. van Schieveen, seorang anggota dewan Vereniging van Indische Boekhandelaren, Perkumpulan Pedagang Buku Belanda yang didirikan tahun 1926. Dalam booklet itu Schieveen menekankan pentingnya membaca bagi perkembangan Indonesia, tetapi juga memperingatkan industri penerbitan Belanda bahwa bahasa kedua yang menjadi pilihan publik Indonesia tampaknya adalah bahasa Inggris, bukan bahasa Belanda. Sebagai solusi agar bahasa Belanda tetap dipakai di Indonesia, Schieveen menyarankan dilakukan distribusi buku berbahasa Belanda secara besar-besaran di seluruh Indonesia. G. Ockeloen, editor Madjallah perdagangan buku di Indonesia/ Maandblad voor de boekhandel in Indonesië (1949), merespons seruan Schieveen. Ockeloen mengatakan bahwa apa yang dikatakan Schieveen adalah benar dan ia bahkan menyebutkan terjadinya krisis buku-buku lain, yaitu buku-buku berbahasa Indonesia.

\section{Introduction}

In April 1948, members of Stichting Grafisch exportcentrum gathered for their annual meeting in Amsterdam. ${ }^{1}$ During this meeting one of the attendees, Van Schieveen, gave a speech in which he sounded the alarm regarding an ongoing 'book crisis' in Indonesia, referring to the growing shortage of Dutch books (Nieuwsblad voor den boekhandel, 19 October 1926). Van Schieveen was a board member of the Vereniging van Indische boekhandelaren, which was a society of Dutch colonial-publishing companies that had been established in 1926. In his speech, he accused the Dutch government of neglecting the Dutch book trade in Indonesia and he also warned the Dutch publishing industry that the preferred second language seems to have become English instead of Dutch. Furthermore, he also stressed the importance of a reading culture for Indonesia's development. As a way to support the continuing use of the Dutch language, he urged the Dutch publishing industry to distribute large quantities of Dutch books all over the archipelago. The alarm was sounded because it seemed that the Dutch publishing industry was about to lose one of their most important export markets. It appeared, however, to be the tip of the iceberg as it turned out that the shortage of books was not solely a problem for the Dutch.

1) Stichting Grafisch Exportcentrum or Graphic Export Center Foundation. This foundation had been established to promote the export of books and other graphic material produced in the Netherlands.

2) After the Second World War the following publishing houses were a member of this society. Wed. J. Ahrend \& Zoon N.V. (Jakarta), Deli Courant N.V. (Medan), G.C.T. van Dorp \& Co N.V. (Jakarta, Bandung, Semarang and Surabaya), Drukkerij Makassar N.V. (Makassar), R.K. Boekhandel Glorieux (Jakarta), N.V. H. Van Ingen (Surabaya), G. Kolff \& Co. N.V. (Jakarta, Cheribon, Surabaya), Moderne Boekhandel (Surabaya) Neyenhuis \& Co. N.V. (Jakarta, Bandung), Stichting Opbouw-Pembangoenan (Jakarta), Varekamp \& Co. N.V. (Medan), Visser \& Co. N.V. (Batavia, Bandung), N.V. Maatschappij Vorkink (Bandung).
... penerbit

Belanda; pasca Perang

Dunia II 


\section{Impact of the Second World War}

In August 1945, the Second World War came to an end. Soekarno and Hatta proclaimed Indonesia's independence which marked the beginning of the Indonesian National Revolution. This period gave way to the development of new ideas. A growing number of people in Indonesia started to gain an interest in certain topics such as politics, and with that, the need for a 'critical mind' evolved (Cultureel nieuws Indonesië, 1952:1 78-179). The thirst for knowledge and therefore books rapidly increased but problems arose. The war had been disastrous for the publishing industry in general. The Japanese had strictly censored the Indonesian publishing industry and the Dutch colonial publishing industry ceased to operate as most of the Dutch were interned during the war and the Japanese had proscribed the use of the Dutch language. ${ }^{3}$ After the Second World War, a number of factors impeded the recovery of the publishing industry in Indonesia. However, various Dutch colonial publishing houses decided to continue their businesses in Indonesia after the war for example, Van Hoeve, G.C.T. Van Dorp \& Co and the Moderne Boekhandel. Most of the Dutch staff were still in internment camps and would only be able to return to their businesses in December 1945. It then became clear that not everyone had survived the war. Among the survivors there were those who wished to return to the Netherlands. According to a commemorative book of one of the Dutch publishing houses, G. Kolff \& Co., members of its staff had found the company had become 'an inanimate publishing house, where Indonesian and Chinese employees did not want to work because of fear of reprisals and more than half of the European workers were missing.' (Door Tyd en Vlyt, 1948: 97). Before the war Kolff had been one of the biggest Dutch colonial publishing companies with several locations across Java. The state of other Dutch colonial publishing houses varied. In general, and on a more practical level, almost every company in the publishing industry in Indonesia had to deal with the severe shortage of paper and ink. Most of the printing machinery and equipment had been damaged during the war and needed to be repaired or replaced. One of the most pressing issues, however, was the lack of skilled employees.

\section{Establishing Education and Training Programs}

The book and publishing industry lacked sufficient numbers of trained personnel in the fields of publishing, printing and graphic design.

3) However, this prohibition was applied in every situation. In some of the internment camps internees were allowed to read Dutch books and there were even libraries. For example, the internment camp Tjikoedapateuh in Bandung. Nederlands Instituut voor Oorlogsdocumentatie, Amsterdam, collectie 400 Indische Collectie, inv. no. 2701. Loe de Jong (1969), Het Koninkrijk der Nederlanden in de Tweede Wereldoorlog, Martinus Nijhoff: Den Haag, dl. 11b, p. 738 and p. 845. W.H.J. Elias (1988) De Japanse bezetting van Nederlands-Indië, J.D. Franken \& Zn. Deventer, p.159. 
Furthermore, there had not been a centrally organized school for graphic education as most of the education seemed to have been done in-house through apprenticeships. Further, management functions and more specialized functions had often been carried out by European staff. In 1949 G. Ockeloen, proposed to organise a course specifically meant for training Indonesian booksellers. ${ }^{4}$ The course would include elementary knowledge about producing paper and letters, bibliography, bookkeeping, management and sales within the context of a bookshop (Ockeloen: 1949). Eventually, the course was printed in the magazine Madjallah perdagangan buku di Indonesial Maandblad voor de boekhandel in Indonesië, which was edited by Ockeloen. The course was printed in this magazine because of the low participation rate and the high cost of running the course. ${ }^{5}$

By the beginning of the 1950s, a technical report regarding the establishment of vocational training for printmakers, graphic designers and other technical employees within the book industry was presented to the Minister of Industry and Trade, Sumitro Djojohadikusomo. The report was handed over by a delegation comprising B.M. Diah, Director of the newspaper Merdeka, And Jan Goan, Director of the newspaper Sin Po and J.C. Fock of type foundry 'Lettergieterij Amsterdam v/h Tetterode'. The report urged that it was necessary to train employees as soon as possible, at the lowest possible cost as the book industry was in considerable need of employees with relevant skills. Training programs had to be organized on a regional level and in Jakarta there would be a school for further education which included a laboratory for scientific research to support the graphic industry, for instance the production of ink and gums (Java bode 26-10-1950).

\section{The English Language}

Furthermore, it became clear that most of the available literature in Indonesia was outdated. For that reason, the Dutch colonial publishers in Indonesia reached out to the motherland for support, but the print runs could barely meet the demand in the Netherlands itself. The message was clear and simple:

4) G. Ockeloen who had worked for the Dutch publishing house G. Kolff \& Co, later would be mostly known for his praiseworthy effort to create several catalogues in which he tried to collect all the titles that were published in the Netherlands-Indies and later on in Indonesia. These are the following catalogues, including the original spelling and place names. G. Ockeloen, Catalogus van boeken en tijdschriften uitgegeven in Ned. OostIndië van 1870-1937, Kolff (Batavia/Amsterdam), 1939-1940.; G. Ockeloen, Catalogus dari boekoe-boekoe dan madjallah-madjallah jang diterbitkan di Hindia Belanda dari tahoen 18701937, Kolff (Batavia etc.), 1939-1940, G. Ockeloen, Catalogus van in Ned.-Indië verschenen boeken in de jaren 1938-1941 en enkele aanvullingen op de gestencilde catalogus verschenen in 1939, Kolff (Batavia/Soerabaia/Amsterdam), 1942.; G. Ockeloen, Catalogus dari buku-buku jang diterbitkan di Indonesia, Kolff (Bandung), 1950-1955.

5) G. Ockeloen, 'Madjallah perdagangan buku di Indonesia/Maandblad voor de boekhandel in Indonesië, vol. 1, no. 1, January 1949 and vol 2., no 1, January 1950. 
they had to wait (Van Schieveen, 1949: 16). It was the indifferent attitude of the Dutch government that would lead to Van Schieveens' cri de coeur. During the second half of the 1940s, the Dutch publishing companies in Indonesia had to continuously plead for money from the Dutch government to continue their activities in Indonesia. The Dutch publishers had tried to convince government of the importance of their business overseas, but it turned out to be a tedious process. Looking back now, it is clear that during the Indonesian National Revolution the book industry was not one of the main priorities of the Dutch government.

The need for books in Indonesia was also given attention by the United Kingdom and the United States of America. Both countries, which had played crucial roles in achieving victory during the Second World War, continued to play a role in regional security afterwards as they were involved in the negotiations between Indonesia and the Netherlands. In regards to the Indonesian book industry, both countries tried to get a seat at the table. In 1947, America established the American Information Service and the United Kingdom set up the British Council both of which were based in Jakarta. Each of these institutions had a collection of English manuals and bibliographical sources that were accessible to Indonesians. In addition, both institutions had competent staff so they could provide the Indonesians with books they requested (De Tijd 11 July 1949). How many books these institutions brought into Indonesia is not known yet. ${ }^{6}$ It was only in 1947 that the Dutch publishing companies in Indonesia were able to start importing books from the Netherlands. The involvement of Great Britain and America in the Indonesian book market, more specifically making available English language books, was perceived as a threat by some of the Dutch colonial publishers.

\section{UNESCO Book-Coupons}

There was yet another competitor in the Indonesian book market. In December 1948, UNESCO had initiated the Book Coupon Scheme. After the Second World War, institutions and individuals who lived in a soft currency country and wished to order books from a foreign publisher often found out that they had to pay in a hard currency, something they could not obtain nor possess. ${ }^{7}$ It became a major problem in many countries worldwide, not only for individuals but also for institutions (Zuckerman, 1949: 236). The difficult economic situations in many soft currency countries led to actions being

6) This is an interesting topic that requires more research.

7) 'Hard currency is a stable and reliable form of currency that is issued by the government and widely accepted around the world.' Soft currency is an unstable form of currency that is unconvertable, fluctuates erratically, and/or depreciates against other currencies. Via: https://corporatefinanceinstitute.com/resources/knowledge/finance/ hard-currency/ 
taken by the United Nations by the end of 1940s. Hence, among other things, UNESCO created the Book Coupon Scheme as an attempt to circumvent certain economic barriers. ${ }^{8}$ The UNESCO Courier (1948/1949) states:

Although books and periodicals are the life-blood of a country's cultural life, they must take their place in the long queue of applicants for slices of the foreign currency available. In most countries this total is now very small indeed and scientists and scholars must compete with the general demand for food-stuff and consumer goods, and with industry's need for machinery and raw materials (UNESCO Courier 1948/1949: 6).

UNESCO's Book Coupon scheme facilitated the purchase of scientific, educational and cultural publications in foreign countries in which the coupon was backed by a hard currency. With this scheme, soft currency countries could obtain publications from hard currency countries. It applied to periodicals, books, photocopies of publications and was later on even extended to scientific equipment and educational and scientific films. ${ }^{9}$ The coupons served as a type of cheque which could be bought from a national distributing agency where people could pay for them with their national currency (Zuckerman, 1949: 236). A limited number of coupons valued at USD 40.000 provided free, coming out of UNESCO's Reconstruction funds. Indonesia was one of the countries that received these free book coupons. ${ }^{10}$ Applications for the free book coupons had to be addressed to the national Ministries of Education (Zuckerman, 1949: 237). In 1950, the Netherlands became part of UNESCO's Book Coupon Scheme. However, America and the United Kingdom would be the main players. By 1952, 60 percent of the materials had been purchased in the United States. Another 30 percent was purchased in the United Kingdom, and the remaining 10 percent was purchased from France, Switzerland and other countries that were part of UNESCO's book scheme (Office of Public Affairs Department of State, 1952: 13). Through this scheme, Indonesia, amongst other soft currency countries, could obtain foreign language books.

\section{A Political Debate}

Van Schieveens' speech was turned into a small booklet: 'Boekennood in Indonesië' (Book Crisis in Indonesia) as an attempt to draw greater attention to the so-called crisis that the Dutch publishing industry was facing in Indonesia.

8) UNESCO and its programme IX ACCCESS to Books, UNESCO document code: MC.51/II/11/a, 1952, p. 17.

9) UNESCO and its programme IX ACCCESS to Books, UNESCO document code: MC.51/II/11/a, 1952, p. 17.

10) Request from Government of Indonesia for allocation from the Emergency Aid Fund, UNESCO Executive Board 23rd, 1950. Meeting, 24 August 1950, Paris. UNESCO document number: $23 \mathrm{EX} / 16$, p. 1. 
It instigated a widespread discussion in the media as it was also sent to all the ministers and members of the Dutch parliament (De Locomotief, 6 January 1950). The booklet even gave rise to a political debate in which a member of the Dutch parliament, C.J.M. Ruijs de Beerenbrouck, asked for a clarification from the Minister for Overseas Territories, J.H. Van Maarseveen. He asked whether it was true that the foreign exchange policy of the Indonesian government endangered the future of Dutch books in Indonesia and if the English language was a rising threat. ${ }^{11}$ It took one month for the minister to reply and in the meantime, the newspaper Het nieuwsblad voor Sumatra had made a mockery of the situation in one its columns. The author, Jodocus (probably an alias), wrote that a cleaner had found a draft response in the trash that said: 'On the contrary, the minister believes that, especially in Indonesia, excessive knowledge of literature has a negative influence on the control of the social system. The minister remembered the old Dutch proverb: 'wat niet weet, wat niet deert / ignorance is bliss' (Het Nieuwsblad voor Sumatra, 18 July 1949).' Ultimately, Van Maarseveen addressed the questions posed by Ruijs de Beerenbrouck. The minister denied that the English language endangered the future of Dutch books in Indonesia. He accused Van Schieveen of not giving an accurate representation of the situation. However, he did confirm that the English and Americans were providing books for free. In addition, the minister agreed with Ruijs de Beerenbrouck that the greatest possible import of Dutch books in Indonesia was important to maintain and strengthen the cultural ties between the Netherlands and Indonesia. ${ }^{12}$ Nonetheless, there was also another counter-argument to Van Schieveen's booklet, that came from an unexpected quarter and shed new light on the very idea of a book crisis in Indonesia.

\section{A Dissenting Opinion}

Soon after Boekennood in Indonesië (Book Crisis in Indonesia) was issued, there was a dissenting opinion published in 'Madjallah perdagangan buku di Indonesia/ Maandblad voor de boekhandel in Indonesië by Ockeloen, the magazine's editor. He wrote that Van Schieveen was stating the obvious. According to him there was an even larger crisis going on in Indonesia, which was, in fact, the shortage of books in Bahasa Indonesia. He wrote that this was only felt by those who were directly impacted. It seems that Ockeloen had quite a farsighted vision when it came to the complicated situation that was unraveling within the book industry of Indonesia. According to Ockeloen, several factors played a role in this Indonesian book crisis. He mentioned the shortage of paper and the high costs that were involved in publishing a book in Indonesia. Furthermore, he wrote that there was a great demand

11) Aanhangsel Eerste Kamer 1948-1949 no. 30. Via: www.statengeneraaldigitaal.nl.

12) Aanhangsel Eerste Kamer 1948-1949 no. 30. Via: www.statengeneraaldigitaal.nl. 
for popular-scientific books, original and translated novels, school books and books for combating illiteracy. ${ }^{36}$ Later in his rebuttal, he wrote that that books in Bahasa Indonesia were still scarce because of the poor organization of the Indonesian book and publishing industry. Ockeloen wrote:

'the Indonesian book industry is not able to break the vicious circle because it is lacking in professional knowledge, and there is no willingness to buy books amongst the reading public because of the poor organization of the Indonesian book industry and they are so poorly organized because the audience is not willing to buy (Madjallah perdagangan buku di Indonesia/Maandblad voor de boekhandel in Indonesië, 1949: 1)'.

In other words, the Bahasa Indonesia book market was too small to be profitable for Indonesian publishers. This issue goes right to the heart of some other problems Indonesia had to face. Books were expensive and most of the audience probably did not have enough money to afford books. Besides, the majority of Indonesians were still illiterate.

\section{Who Was Able to Read?}

On a practical level there was a crisis, with the shortage of paper, ink, wellfunctioning machinery and the lack of skilled employees. On a whole other level, the book market needed an audience; people that were able to read. Education had been placed high on the political agenda of the Indonesian government (Van der Kroef, 1955: 366). It was seen as a way to create a society of 'sama rasa sama rata', in other words, an egalitarian society (Soekarno, 1957: 3). The policy of combating illiteracy was closely associated with the improvement of the educational system. By the beginning of the 1950s, Indonesia had an illiteracy rate of around 80 per cent, which meant that 56 to 60 million people were not able to either read or write (Finkelstein, 1951: 149; Lubis 1952: 93; Ross Jenney, 1953: 411). ${ }^{13}$ This high illiteracy rate was part of Indonesia's colonial legacy within the educational field. The Dutch had set up a school system that was based on the different social classes within the colonial society. There were schools for Dutch children and the Indonesian elites that used Dutch as the medium of instruction. While at village schools the Indonesian children were taught in a local language or Malay (Hanan Habib, 1983: 15). Only a small minority of the Indonesian population had access to a 'European-style' education, after which many continued their training at universities in the Netherlands. This system produced nationalist leaders, such as Soekarno and Sjahrir, and most students came from royal and aristocratic families in Indonesia (Finkelstein 1951: 149).

When it came to the Dutch language, less than two percent of Indonesians had mastered the language by 1940 (Groeneboer 1998: 7). This

13) It is estimated that there were about 70 million Indonesian by this time. 
was roughly over one million Indonesians of which about half a million had a good command of the Dutch language and another half a million had receptive language skills, which meant that they were able to comprehend spoken or written Dutch (Groeneboer 1998: 8). Furthermore, it is estimated that there were about 260000 Dutch in Indonesia after the Second World War. Moreover, Van Schieveen has also made a calculation in Boekennood in Indonesië about what he called 'the intelligentsia', which were those who had a good command of the Dutch language and required Dutch books. According to him, there were about 70 million Indonesians in the second half of the 1940s. Of these 70 million, only 0.5 percent was part of the so-called intelligentsia, which amounted to about 350000 people (Van Schieveen, 1949: 8). The numbers stated above are an estimation as demographic information is very limited. They do nevertheless underline the fact that only a very small percentage within Indonesia, taking into account both Indonesians and Dutch, required Dutch books. So, the need for Dutch books was, in particular, a matter for the Dutch who stayed in Indonesia after the Second World War and for Indonesian intellectuals. On the other hand, these figures show what Ockeloen already argued in his magazine, namely the increasing need for books in Bahasa Indonesia.

\section{The Foreign Exchange Problem}

In March 1950, the Indonesian government decided to increase the prices of imported books to give priority to domestically published books. The idea behind this was to enable the Indonesian publishing industry to gain a greater share of the market. However, most books in Dutch and Bahasa Indonesia and even in English still had to be imported due to the fact that foreign books produced overseas were cheaper and of better quality. Because of differences in the exchange rate, Dutch books subsequently became 250 percent more expensive, whilst the prices of other foreign books increased by 157 percent. These increases in prices made it more risky for most of the booksellers in Indonesia to order foreign books. (Nieuwe Courant, 4 May 1950). They were afraid that imported books would become unsellable due to these exceptionally high book prices.

In 1951, the Indonesian government decided to cancel their decision to increase the prices on imported books as the Indonesian publishing industry was not yet able to meet the high demand for books. The imported books were found to be still very necessary for Indonesia's development. There was a great shortage of new school books, which were necessary to improve literacy rates as well as to educate the next generation. Furthermore, there was a lack of teachers at every level within the existing education system, which was a growing problem for Indonesia (Cultureel Nieuws Indonesië, 1951: 19). The Indonesian government was thus forced to cooperate with the remaining 
Dutch publishing companies in Indonesia. These companies did their business through branch offices in Indonesia and often already had commercial contacts with Indonesian colleagues within the field. The ministry commissioned books by several Dutch publishing houses, for instance, Wolters, Kolff \& Co., G.C.T. van Dorp, Balai Pustaka and Opbouw-Pembangunan, but also De Moderne Boekhandel and Van Hoeve were widely known for working with the Indonesian government. Most of the commissioned books had to be imported from the Netherlands (Cultureel Nieuws Indonesië, 1951: 1).

\section{A New Direction}

Out of all the book genres, scientific literature was found to be the most necessary for the development of Indonesia. This is the likely reason why much of the cooperation between Dutch publishing companies and the Indonesian government seemed to involve scientific publications. Due to the high demand, this became the most profitable niche within the Indonesian book market. The shortage of books in Bahasa Indonesia gave way to a new direction for some of the Dutch publishing companies in Indonesia as they decided to start catering for the Indonesian market by publishing books in Bahasa Indonesia. This was an obvious publishing strategy as the prices for foreign books went up again in June 1951. Nevertheless, it seems that these publishing companies were not able to fill the high demand for books. When it came to the production of scientific work in Bahasa Indonesia there were not yet enough Indonesian scholars producing manuscripts or their manuscripts were lacking in quality. ${ }^{14}$ This was why Indonesia was forced to work with books written by foreign researchers. Books had to be translated into Bahasa Indonesia, which touches upon another issue, that of translation. This is an important topic, but will only briefly be touched upon in this paper. At that point in time still, a very small percentage of the Indonesian population was able to read and write and could work as professional translators, which meant a good knowledge of at least two languages. Indonesia needed translators, and this also explains why other languages for instance, English and even Dutch stayed in the picture, due to the simple fact that Indonesia was desperately in need of knowledge to build up the country. There were not enough translators at that time and translating books was time-consuming.

\section{An Import Ban}

In 1956 the Indonesian government decided to ban the import of books in Bahasa Indonesia, which it can be assumed were mostly published by Dutch publishing houses in the Netherlands. Moreover, books that were printed

14) E. Douglas Pearce, Book development: Indonesia - (mission) SeptemberDecember 1973. UNESCO document code: 3043/RMO.RD/DBA, FR/UNDP/INS/72/024, 1974, p. 16. 
in Indonesia were about the same price as imported books. This had to do with the fact that the majority of the materials, for instance, paper and ink, still had to be imported. With the nationalization of the Dutch companies, which started at the end of 1957, the Dutch publishing industry came to an end. Although Dutch influence came to an end, Indonesia still had to rely on foreign language books and translated books. Later on, it became clear that there was not only a book shortage in Indonesia, but that the coverage of particular disciplines was also lacking. It was relatively easy for Indonesian commercial publishing companies to print and sell textbooks on accountancy, law and management. When it came to the subjects as archaeology or anthropology, it was virtually impossible to envisage a big enough market to justify commercial publishing. ${ }^{15}$

\section{Conclusion}

The book shortage crisis touches upon a myriad of issues Indonesia had to deal with in the late 1940s and the early 1950s. The discussion between Van Schieveen and Ockeloen illustrates that two different crises were going on, which did intertwine on some levels. The Dutch book crisis in Indonesia had a lot to do with the commercial interests of the Dutch publishing industry, but this crisis came to an end with the nationalization of Dutch industries between 1957 and 1958. The book crisis that Ockeloen examined in his magazine, however, continued. Although the Indonesian publishing industry was able to publish most of the titles in Bahasa Indonesia, they still had to deal with the same difficulties as at the beginning of the 1950s. The actual problem lay in production, in which Indonesia encountered many problems, both on a practical level of book production as well as creating and obtaining the actual knowledge itself.

\section{References}

\section{Archives}

Aanhangsel Eerste Kamer 1948-1949 no. 30. Via: www.statengeneraaldigitaal.nl. Douglas Pearce, E., Book development: Indonesia - (mission) September-December 1973. UNESCO document code: 3043/RMO.RD/DBA, FR/UNDP/ INS/72/024, 1974.

Nederlands Instituut voor Oorlogsdocumentatie, Amsterdam, collectie 400 Indische Collectie, inv.no. 2701.

Request from Government of Indonesia for allocation from the Emergency Aid Fund, UNESCO Executive Board 23rd, 1950. Meeting, 24 August 1950, Paris. UNESCO document number: 23EX/16.

UNESCO and its programme IX ACCCESS to Books, UNESCO document code: MC.51/II/11/a, 1952.

15) E. Douglas Pearce, Book development: Indonesia - (mission) SeptemberDecember 1973. UNESCO document code: 3043/RMO.RD/DBA, FR/UNDP/INS/72/024, 1974, p. 15. 


\section{Magazines and Newspapers}

Cultureel Nieuws Indonesië, no. 6, 1951.

Cultureel Nieuws Indonesië, no. 8, 1951.

Cultureel nieuws Indonesie, no. 17, 1952.

De Locomotief, 6 January 1950.

De Tijd, 11 July 1949.

Het Nieuwsblad voor Sumatra, 19 July 1949.

Java bode, 26 October 1950.

Madjallah perdagangan buku di Indonesia/Maandblad voor de boekhandel in Indonesie, January 1949.

Nieuwsblad voor den boekhandel, 19 October 1926.

Nieuwe Courant, 04 May 1950.

UNESCO Courier, December 1948-January 1949.

\section{Books}

De directie van de uitgeverij (1948), Door tyd en vlyt. Gedenkboek uitgegeven ter gelegenheid van het hondertjarig bestaan van de N.V. Koninklijke boekhandel en drukkerij G. Kolff \& Co, Batavia: Kolff.

Elias, W.H.J. (1988) De Japanse bezetting van Nederlands-Indië, J.D. Franken \& Zn.: Deventer.

Jong, Loe de (1969), Het Koninkrijk der Nederlanden in de Tweede Wereldoorlog, Martinus Nijhoff: Den Haag.

Schieveen, A.P. van, (1949). De boekennood van modern Indonesië, Amsterdam: Stichting Grafisch Exportcentrum.

Soekarno (1960), 'Marhaen and Proletarian. Speech before the Indonesian nationalist Party at the party's Thirtieth Anniversary at Bandung', 3 July 1957, Ithaca N.Y.: Cornell University.

\section{Journal Articles}

Finkelstein, Lawrence S., 'Education in Indonesia', Far Eastern Survey 20,15: 149-153. Groeneboer, Kees, 'Westerse koloniale taalpolitiek in Azië: het Nederlands, Portugees, Spaans, Engels en Frans in vergelijkend perspectief, Mededelingen van de Afdeling Letterkunde.Nieuwe reeks, 62:2, 1-27.

Hasnan Habib, A.'The role of Education in the Indonesian Nation Building and National Development', Focus on Indonesia, Autumn/Winter 1983: 14-17.

Kroef, Justus M. van der, 'Higher Education in Indonesia', The Journal of Higher Education 26:7, 366-377.

Lubis, Mochtar, 'The Press in Indonesia', Far Eastern Survey 21, 9: 90-94.

Office of Public Affairs Department of State, 'Economic and Social Problems in the United Nations', A Current Review 4, 1: 1-14.

Ross Jenny, E., 'Public Health in Indonesia', Public Health Reports, 68,4: 409-415.

Zuckerman, Jacob. 'UNESCO Book Coupon Scheme.' Notes 6,2: 236-238. 